\title{
Toprak Üstü Biyokütle Potansiyelinin CBS ve Uzaktan Algılama ile Belirlenmesi - Yeni Bir Yaklaşım
}

\section{Assessment of Aboveground Biomass Potential by GIS and Remote Sensing - A New Approach}

\author{
Fulya Aydın-Kandemir ${ }^{1}(\mathbb{0}$, Hasan Sarptaş²*৫) \\ ${ }^{1}$ Ege Üniversitesi Güneș Eneriisi Ens., 35100, İzmir, TÜRKIYE ve Hidropolitik Akademi, 06680 K.dere, Ankara, TÜRKIYE \\ ${ }^{2}$ Ege Üniversitesi Güneș Enerjisi Enstitüsü, 35100, İzmir, TÜRKIYE \\ Sorumlu Yazar / Corresponding Author* : hasan.sarptas@ege.edu.tr
}

\author{
Geliş Tarihi / Received: 19.05.2021 Araștırma Makalesi/Research Article \\ Kabul Tarihi / Accepted: 23.09.2021 DOI:10.21205/deufmd.2022247016 \\ Atıf șekli/ How to cite: KANDEMIR, F.A.,SARPTAȘ, H.(2022). Toprak Üstü Biyokütle Potansiyelinin CBS ve Uzaktan Algılama ile Belirlenmesi - \\ Yeni Bir Yaklașım. DEUFMD, 24(70), 165-178.
}

Öz

Ülkemizde potansiyel açısından en önemli biyokütle kaynağı konumunda olan orman biyokütlesinin alansal dağılımının belirlenmesi, biyokütle stoklarının izlenmesi ve orman biyokütlesinden enerji üretimi projelerinin teknik ve ekonomik uygulanabilirliğinin saptanması açısından kritik öneme sahiptir. Orman envanterlerinde tek tek her ağaç için yapılan yaş, boy, çap ve gövde hacmi gibi arazi ölçümleri ve hesaplamalarına göre önemli avantajlar sunan Uzaktan Algilama (UZ-AL) tekniği ile Coğrafi Bilgi Sistemleri (CBS)'nin entegrasyonu, biyokütle potansiyelinin daha kapsamlı ve hızlı bir şekilde belirlenmesine olanak sağlamaktadır. Bu noktadan hareketle, bu çalışmada, orman biyokütle potansiyelinin tahminlenmesi (haritalanması) için CBS ve UZ-AL tekniklerini bütünleştiren bir yöntem geliştirilmesi ve örnek bir çalıșma bölgesinde uygulanması amaçlanmıștır. Çalışma kapsamında, çalıșma bölgesi olarak seçilen Bergama İncecikler Orman Şefliği sınırlarındaki toprak üstü biyokütle (TÜB) potansiyeli, ormanlardaki karbon hesaplanmasında kullanılan yaklașımla tespit edilmiştir.

Anahtar Kelimeler: biyokütle, toprak üstü biyokütle (TÜB), coğrafi bilgi sistemleri, uzaktan algılama, SENTINEL-2

\begin{abstract}
Assessment of the spatial distribution of forest biomass, which is the most important biomass source in terms of potential in Turkey, has a critical prospect for monitoring biomass stocks and determining the technical and economic feasibility of energy production projects from forest biomass. The integration of Geographical Information Systems (GIS) with Remote Sensing (RS) technique, which provides significant advantages according to land measurements and calculations such as age, height, diameter and trunk volume for each individual tree in forest inventories, provides a more comprehensive and faster biomass potential estimation. For this respect, this study aims to develop a method integrating GIS and RS techniques for the estimation (mapping) of forest biomass potential and to implement it in a case study area. Within the scope of the study, above-ground biomass potential for Bergama İncecikler Forestry Area has been determined by IPCC method.

Keywords: biomass, aboveground biomass (AGB), geographic information system, remote sensing, SENTINEL-2
\end{abstract}




\section{Giriş}

Orman biyokütlesi, yapı malzemesi olarak, kâğıt hamuru ve kâğıt üretiminde ve yakıt olarak enerji üretiminde önemli bir hammaddedir. Bununla birlikte, ormanlar, odunsu biyokütleleri içinde büyük miktarlarda karbon yakalayıp depoladıkları için dünya iklimi için önemli bir düzenleyici olarak da tanımlanır [1],[2]. Birleşmiş Milletler İklim Değișikliği Çerçeve Sözleşmesi kapsamında 1997 Kyoto Protokolü'nün kabul edilmesinden sonra, karbondioksitin büyük karasal depolayıcısı - ve kaynağı - olarak ormanların rolü daha da anlaşılmıştır [3].

Orman biyokütlesi, binlerce yıldır kullanılan en eski enerji kaynağıdır. Günümüzde enerji arzında ana kaynak konumundaki fosil yakıtların azalan rezervleri, artan üretim maliyetleri, enerjide dışa bağımlılık ve iklim değişikliği başta olmak üzere ciddi çevre sorunları gibi önemli dezavantajları nedeniyle, diğer yenilenebilir enerji formları yanında orman biyokütlesi, enerji kaynağı olarak yeniden önem kazanmıștır. Ülkemizde halen elde edilmekte olan biyokütle enerjisinin \%64'ü odun ve odun atıklarından, \%24'ü kentsel katı atıklarından, \%5'i tarımsal atıklardan ve $\% 5$ 'i ise katı atık depo gazından üretilmektedir [4]. $\mathrm{Bu}$ açıdan değerlendirildiğinde, bölgesel ya da ulusal ölçekte biyokütle varlığının ortaya konmasında orman biyokütlesinin önemi büyüktür.

Orman ekosistemleri büyük miktarlarda karbon barındırdığı için bölgesel ve küresel karbon (C) çevriminde önemli bir role sahiptir [3, 5-11]. Bu nedenle de ormanların içerdiği karbon (biyokütle) miktarının doğru şekilde tahmini konusunda artan bir ihtiyaç söz konusudur. Ekosistemin üretkenliği, karbon bütçeleri, besin dağılımları - ve biyokütlenin sahip olduğu yakıt potansiyelinin tahmini için, toprak üstü biyokütle (TÜB) kaynakları ile ilgili bilgilerin (mevcudiyeti, alansal ve zamansal değișimi, vb.) üretilmesi gerekmektedir. Toprak üstü orman biyokütlesinin haritalanması, biyoenerji potansiyelinin tahmini, arazi kullanım ve arazi örtüsü değişimlerinden kaynaklanan $\mathrm{CO}_{2}$ emisyonlarının tahmini ve karbon (biyokütle) stoklarının izlenmesi için temel öneme sahiptir [9].

Toprak üstü orman biyokütlesi potansiyeli (karbon stoğu), klasik olarak arazi ölçümleri ile elde edilen değerler esas alınarak hesaplanır.
Emek yoğun ve zaman alıcı bu yönteme alternatif bir yöntem, yeni ve etkin bir yaklaşım sağlayan Coğrafi Bilgi Sistemleri (CBS) ve Uzaktan Algılama (UZ-AL) teknikleri desteği ile tahminlemedir. UZ-AL, arada mekanik bir bağlantı olmaksızın bir cisimden yayılan veya yansıtılan elektromanyetik ışınımın nitelik ve nicelik yönünden değerlendirilmesi ile cismin özelliklerinin uzaktan ortaya konması ve ölçülmesine dayanmaktadır [12],[13]. UZ-AL teknikleri sayesinde yeryüzünden belli bir uzaklıkta, atmosfer veya uzaydaki platformlara yerleștirilmiș ölçüm aletleri aracılığıyla, yeryüzü ve yeryüzü objeleri görüntülenebilmektedir [14],[15]. Bu yolla özellikle son yıllarda, uydu görüntülerinin artan mevcudiyeti/ulaşılabilirliği sayesinde, UZ-AL tabanlı yöntemler, toprak üstü biyokütle tahmininde en çok kullanılan yaklaşımlar olmuştur.

UZ-AL alanındaki gelişmeler, orman biyokütlesinin tahmini için yeni ve etkin bir yol açmıştır. UZ-AL teknikleri sayesinde üretilen görüntülerin yorumlanması ve bu görüntülerden bilgi elde edilmesi amacı ile gerçekleştirilen piksel tabanlı ve nesne tabanlı (segmentasyon) görüntü sınıflandırma teknikleri, arazide ölçüm gibi yaklaşımlara göre daha hızlı ve pratik sonuçlar vermektedir. Meinel ve Neubert [16]'e göre, UZ-AL'da görüntü çözünürlüğünün artması, piksel tabanlı sınıflandırma teknikleriyle birlikte özellikle segmentasyon yöntemlerine daha da önem kazandırmaktadır.

UZ-AL aracılığıyla üretilen veriler, düşünsel değil, farklı teknikler kullanılarak elde edilen yer yüzeyini ölçmeye dayalı bilgiler olduğundan bilgisayar destekli konumsal bilgi işleme, depolama ve arşivleme sistemi olan CBS için önemli bir veri kaynağıdır $[15,17]$. UZ-AL ile çok kısa zaman aralıklarında ve çok geniș arazi parçaları hakkında veri elde edilebilir [17]. Geniș alanlarla ilgili bilgiler, CBS ortamına aktarıldığında analiz edilebilir ve diğer verilerle birleștirilebilir [18].

Tüm bu bilgilerin ışığında arazi ölçümleri, jeoistatistik enterpolasyon tekniklerinin kullanıldığı modelleme yaklaşımları, UZ-AL ve CBS teknikleri aracılığıyla toprak üstü biyokütle potansiyeli tahmin edilebilmektedir. Uzaktan algılama görüntülerinden elde edilen veriler ile arazi ölçümlerinin ve jeoistatistik enterpolasyon tekniklerinin birleștirilmesi orman biyokütle 


\section{DEÜ FMD 24(70), 165-178, 2022}

kaynaklarının daha yüksek doğrulukla haritalanmasını sağlar.

UZ-AL ile toprak üstü orman biyokütle potansiyeli belirleme çalışmalarında, yukarıda belirtildiği üzere, genellikle arazi ölçümleri temel alınarak tahminleme yapılmaktadır. Ancak bu ölçümlere geniş ölçekte, yeterli konumsal hassasiyette ve güncel olarak ulaşmanın zorluğu dikkate alınarak bu çalışmada arazi ölçümleri olmadan UZ-AL, görüntü işleme ve CBS teknikleri ile toprak üstü orman biyokütle potansiyelinin tahminlenmesi için nesne tabanlı sınıflandırma yaklașımının geliștirilmesi ve örnek bir çalışma sahasına uygulanması amaçlanmıştır.

\section{2. Önceki Çalışmalar}

UZ-AL ve görüntü işleme teknikleri ile görüntü sınıflandırma yöntemleri ve orman biyokütle potansiyelinin (karbon depolama kapasitesi) ve bu potansiyelin zamana bağlı değișiminin UZ-AL ile belirlenmesi ve değerlendirilmesine yönelik çalışmalar günümüzde giderek yaygınlaşmaktadır.

Askar vd. [19] Sentinel-2 görüntüleri kullanılarak türetilen vejetasyon (bitki örtüsü) indekslerinden özel ormanların toprak üstü biyokütlesini (TÜB) tahminleme potansiyelini araştırmıștır. Bu amaçla 45 örnek parsel ve 7 vejetasyon indeksi çalıșılmıș ve Normalize Edilmiş Fark İndeksi (Normalized Difference Index-NDI) ile TÜB arasında en yüksek korelasyonu $\left(\mathrm{R}^{2}=0.79\right)$ sağladığı saptanmıstır. Burada, TÜB ve bitki örtüsü indeksleri arasında model oluşturmak için aşamalı doğrusal regresyon $\left(\mathrm{R}^{2}=0.81\right)$ kullanılmıștır. Ayrıca, konumsal analiz sonucunda çalıșma alanındaki toprak üstü biyokütlesinin 72.54 ton/ha olduğu tespit edilmiștir. Öngörülen ve gözlenen toprak üstü biyokütle için kök ortalama kare hatası (root mean square error - RMSE) ise 27 ton/ha olarak bulunmuştur. Çalışma alanındaki toprak üstü biyokütle değerinin bazı orman türlerindeki toprak üstü biyokütle değerinden daha yüksek olduğu ve özel ormanların biyokütle depolaması için iyi bir seçenek oluşturduğu tespit edilmiștir. Genel olarak, Sentinel-2 çok-bantlı görüntüleri ile oluşturulan bitki örtüsü indekslerinin, özel ormanlar için toprak üstü biyokütle raporlanması açısından iyi sonuç sağladığı ortaya konmuştur.

Goodenough vd. [20] Kanada'da yaptıkları çalışmada hiperspektral AISA Eagle verilerini
AVIRIS verileri ile karșılaștırmıștır. Burada iki metre yersel çözünürlüklü AISA verileri ve LIDAR verileri, Victoria Üniversitesi (UVic) tarafından Büyük Victoria Havza Bölgesi (GVWD) test alanı için elde edilmiș ve NASA'nın 2002 yılına ait $4 \mathrm{~m}$ yersel çözünürlükte elde edilen AVIRIS verileri ile karşılaştırılmıştır. LIDAR verileri, toprak üstü biyokütle tahminlerini sağlamak için ağaç yüksekliklerinin tespiti ve allometrik denklemlerin değerlendirilmesinde kullanılmıștır. Yapılan çalışmada her iki görüntünün de makul orman TÜB tahminlerinin türetilmesinde bașarıyla kullanılabileceği ifade edilmiştir. Özellikle ana orman türleri için ortalama sinıflandırma doğruluğu \%89 olarak hesaplanmıștır.

Verkerk vd. [21] odunsu biyokütle potansiyellerinin 2020 yılı için konumsal dağılımını, kök odun, artıklar (dallar ve hasat kayıpları) ve ağaç kütüğü bazında 39 Avrupa ülkesi için değerlendirmiștir. Çalışmada Avrupa Orman Bilgi modeli (SCENario - EFISCEN) ve uluslararası orman istatistikleri kullanılmıș ve büyüyen stok ve artış ve orman yönetimi rejimlerine dayanarak orman yaş yapısının mevcut ve gelecekteki gelişiminin elde edebileceği teorik biyokütle miktarı tahmin edilmiștir. Elde edilen bu tahminler, potansiyel olarak odunsu biyokütle miktarını azaltan bir dizi olası çevresel (saha verimliliği, toprak ve su koruma ve biyoçeşitlilik koruması) ve teknik (geri kazanım oranı, toprak taşıma kapasitesi) kısıtlamalar ile birleştirilmiștir. Bunların yanı sıra odunsu biyokütle potansiyellerinin konumsal dağılımına ilișkin bilgi edinmek için idari birimler düzeyinde ve $10 \mathrm{~km}$ yersel çözünürlükte potansiyel biyokütle kullanılabilirliği haritalanmıştır. Gerçekleştirilen bu çalışmada, orman biyokütlesinin toplam kullanılabilirliğinin yılda 357 ile 551 milyon ton kuru madde arasında değișmekte olduğu tespit edilmiștir. Birim arazi bașına en büyük odunsu biyokütle kaynağının kuzey Avrupa (güney Finlandiya ve İsveç, Estonya ve Letonya), orta Avrupa (Avusturya, Çek Cumhuriyeti ve güney Almanya), Slovenya, güneybatı Fransa ve Portekiz'de bulunduğu saptanmıştır. Bununla birlikte, bu potansiyellerin büyük bir kısmının halihazırda malzeme ve enerji için kullanılmakta olduğu da çalıșmada belirtilmiștir. Halen kullanılmayan biyokütle potansiyellerinin dağılımının ise günümüzde yüksek seviyede odun üretimine sahip bölgelerle kısmen 


\section{DEÜ FMD 24(70), 165-178, 2022}

örtüşmekte olduğu ifade edilen bir diğer sonuçtur.

Özkan [22], SPOT-5 uydu verileri segmentasyonunda orman meşcere tiplerinin ayrılabilirliğini ve uydu görüntüleri reflektans (yansıma) değerleri ile meșcere parametrelerinin tahminlenebilirliğini araştırmıştır. Çalışmada, amenajman planı düzenlemesi amacıyla meşcere tipleri ayrımının SPOT-5 verisi ile yapılamayacağı belirtilmiştir. Bununla birlikte üretilen verinin ulusal veya bölgesel bazda orman envanterlerinde kullanılmasının olanaklı olacağı belirlenmiștir.

Artvin ve Bulanıkdere işletme șeflikleri için Sivrikaya vd. tarafından Landsat ETM+ verileri ve yeniden sınıflandırılmış meşcere haritaları kullanılarak arazi kullanım haritaları oluşturulmuştur [23]. Arazi kullanım haritalarının doğruluğu test edilerek bu iki șeflik için de bu haritaların kullanılabileceği saptanmıştır.

Chhabra vd. [24], 1992-93 yılları için Orman Bakanlığı tarafından toplam toprak biyokütlesinin (yer üstü ve yeraltı dahil) üç farklı tepe yoğunluğu sınıfında (çok yoğun ormanlar ile - taç örtüsü \% 70 ve üstü, taç örtüsü \% 40, ve taç örtüsü \%10 ila \%40 arasında olan açık ormanlar) dört ana orman kategorisine (sert kerestelik, ladin, çam ve bambu) gruplandırıldığı Hint ormanlarını incelemiştir. Çalışmada, büyüyen stok hacmi, büyüyen stok hacmi yoğunluğunun fonksiyonu olarak ve biyokütle genişleme faktörleri kullanılarak toplam biyokütleye dönüştürülmüştür. Hindistan ormanlarında 1992-93 çalışma yılı için ortalama büyüyen stok hacmi yoğunluğu $74.42 \mathrm{~m}^{3} / \mathrm{ha}$ iken Pencap'ta bu değerin $7.1 \mathrm{~m}^{3} /$ ha ile Jammu ve Kaşmir'de $224.5 \mathrm{~m}^{3} /$ ha arasında değiştiği görülmüştür. Toplam biyokütlenin (toprağın üstünde ve toprağın altında) $8683.7 \mathrm{Mt}$ (Mt = 1012 g) olarak tahmin edildiği bu çalışmada toprak üstü ve altı biyokütlesinin toplam biyokütleye sırasıyla \% 79 ve \% 21 (6865.1 Mt ve $1818.7 \mathrm{Mt}$ ) oranlarında katkıda bulunduğu belirlenmiștir. Hint ormanlarındaki ortalama biyokütle yoğunluğunun $135.6 \mathrm{t} / \mathrm{ha}$ olduğu ve bu değerin Pencap'ta $27.4 \mathrm{t} / \mathrm{ha}$ 'den Jammu ve Keşmir'de 251.8 t/ha'e değiştiği tahminlenmiştir. Tahminler, ilgili süre için 44008700 Mt aralığında biyokütleyi tahmin eden önceki çalıșmalarla karşılaştırılmıştır. Çalışmanın sonucu olarak, artan stok hacmi yoğunluğunun, dört orman tipi ve Hint ormanlarının üç tepe yoğunluğu sınıfının bir fonksiyonu olarak odun hacmini biyokütle ile ilişkilendiren biyokütle genişleme faktörlerini içerdiğinden önceki tahminlerden yüksek olduğu belirtilmiștir.

Iverson vd. [25] tarafından yapılan çalıșmada Güney ve Güneydoğu Asya'daki tropikal ormanların toplam biyokütle ve biyokütle yoğunluğunu tahmin etmek için CBS teknikleri kullanılmıştır. Çalışmada öncelikle, insan veya doğal etkiler olmadığında beklenen biyokütle yoğunluğu modellenmiștir. Bu değer, yükseklik, toprak, eğim, yağıș ve iklim endeksindeki CBS verilerinden elde edilmiştir. Dokuz ülke için toplam orman biyokütlesinin $176 \mathrm{Pg}$ ve ortalama potansiyel biyokütle yoğunluğunun (PBD) 322 $\mathrm{Mg} /$ ha olduğu tahmin edilmiștir. Çalıșmanın bir sonraki bölümünde potansiyel orman biyokütle haritası, 1980 için orman haritası ile maskelenmiş, böylece 1980 'de ormanlardaki meydana gelen potansiyel biyokütle yoğunluğunun haritalanması sağlanmıștır. Bu konumlar için toplam potansiyel biyokütle tahmininin 63 Pg olduğu tespit edilmiștir. Çalışmaya, daha sonra, nüfus yoğunluğunun etkisi de dâhil edilmiștir. 1980 yılında toplam gerçek orman biyokütlesinin ormanlık alanlardaki potansiyel biyokütlenin \% 52'sinin ve tüm alt kıtadaki potansiyel biyokütlenin \% 19'unun azalmasını temsil eden $33 \mathrm{Pg}$ olduğu tespit edilmiștir. 1980 yllı Güney ve Güneydoğu Asya tropik ormanları için gerçek biyokütle yoğunluğunun (ABD) $194 \mathrm{mg} / \mathrm{ha}$ veya insan aktivitesi ve doğal etkiler olmadan öngörülen biyokütle yoğunluğunun \% 52'si olduğu tahmin edilmiștir. Yapılan bu çalıșmada gerçekleștirilen yöntemin tropik bölgelerde biyokütle ve biyokütle değişimini tahmin edebileceği ifade edilmektedir.

Hongrui vd. [26], İç Moğolistan'daki çöl bozkırının biyokütlesini kırmızı kenar yansıtma eğrisi alanı yöntemine göre tahmin etmiștir. Sonuçlar, kırmızı kenar yansıtma eğrisi alanının (normalleștirilmiş yansitma eğrisi ile 680-780 $\mathrm{nm}$ bölgesindeki dalga boyu arasinda) geleneksel bitki örtüsü indeksleri veya tek bașına kırmızı kenar pozisyonu ile karşılaştırıldığında daha iyi performans gösterdiğini ortaya çlkarmıștır. Bu yöntem, optimal dar-bant oranlı vejetasyon indeksine (37.4 $\mathrm{gm}^{-2}$ ) klyasla daha düşük standart tahmin hatası $\left(26.4 \mathrm{gm}^{-2}\right)$ ile sonuçlanmıștır [27]. 


\section{Veri ve Yöntem}

\subsection{Araştırma Sahası}

Bu çalışmada, araştırma sahası olarak İzmir ili Bergama ilçesinde yer alan İncecikler Orman İşletme Şefliği seçilmiştir. Bu şeflik, özellikle Bergama Kozak Yaylası ve civarındaki orman varlığının önemli bir bölümünü barındırdığı için sahip olduğu biyokütle potansiyeli nedeniyle ele alınmıştır. İncecikler Orman İşletme Şefliğinin güneyinde Bergama, kuzeyinde Kozak, doğusunda Madra ve batısında ise Dikili orman işletme șeflikleri yer almaktadır (Şekil 1).

\subsection{Veriler}

\subsubsection{Araștırma sahası sınırları}

Araştırma sahası olan İncecikler Orman İşletme Şefliği sınırları (Şekil 1), Orman ve Su İșleri Bakanlığı Geodata servisinde yer alan orman işletme șeflikleri sınırları verisi kullanılarak sayısallaştırma ile olușturulmuştur. Saha toplam olarak 10056 ha'lık bir alanı kaplamaktadır.

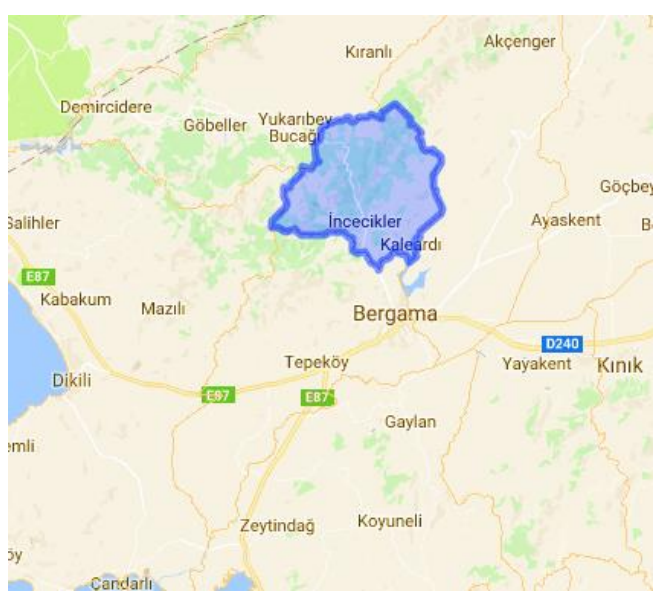

Şekil 1. Araştırma sahası (OGM GeoData)

\subsubsection{Saha topografyası}

Saha topoğrafyasına ait sayısal yükseklik modeli verisi Japonya Ekonomi, Ticaret ve Endüstri Bakanlığı (METI) ile ABD Ulusal Havacılık ve Uzay Dairesi (NASA) tarafından ortaklașa hazırlanan ve ücretsiz olarak dağıtılan ASTER GDEM v2 veritabanından temin edilmiștir [28]. Araștırma sahasındaki arazi yükseklikleri 112 $971 \mathrm{~m}$ arasında değişmektedir (Şekil 2).

\subsubsection{Arazi örtüsü / kullanımı}

Ülkemizin de üyesi olduğu Avrupa Çevre Ajansı, CORINE (Coordination of Information on the
Environment - Çevresel Bilginin Koordinasyonu) Programı kapsamında, tüm Avrupa için uydu görüntüleri üzerinden bilgisayar destekli görsel yorumlama yöntemi ile arazi sınıflandırması ile arazi örtüsü / kullanımı verisi üretilmektedir. Bu çalışmada, araștırma sahasındaki arazi örtüsü / kullanımını ortaya koymak için, CORINE Programı kapsamında IRS P6 LISS III ve RapidEye uydularından elde edilen görüntüler ile hazırlanan ve 2015 yılında kullanıma sunulan CLC2012 (sürüm 18.5) verisi kullanılmıștır. Bu verinin zamansal doğruluğu 2011 - 2012, geometrik doğruluk $\leq 25 \mathrm{~m}$ ve tematik hassasiyeti $\geq \% 85$ 'tir [29] (Şekil 3).

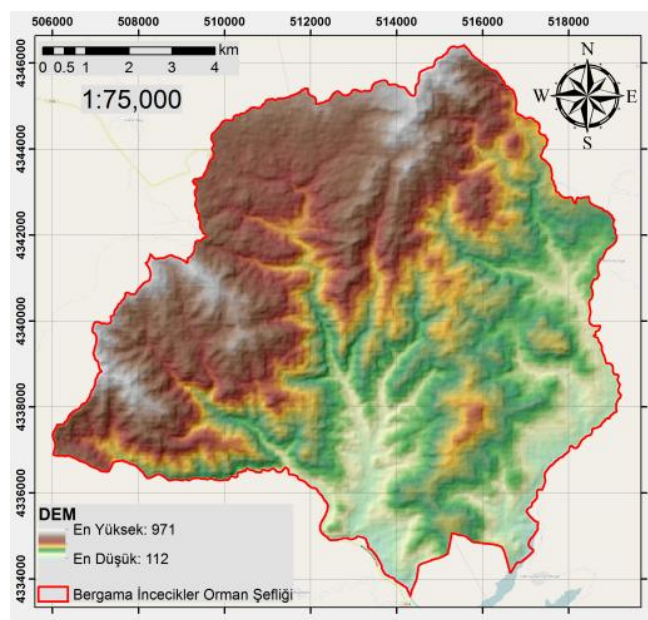

Şekil 2. Araştırma sahası topografyası

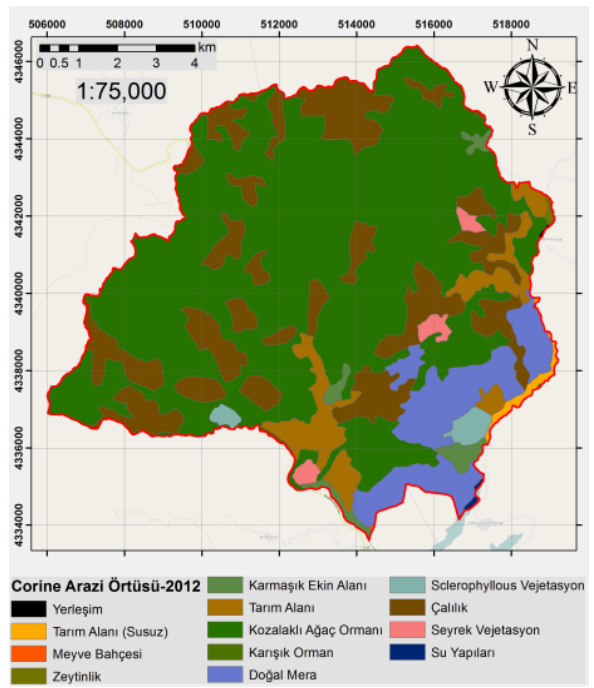

Șekil 3. Arazi örtüsü / arazi kullanım 


\subsubsection{Uydu görüntüleri}

Bu çalıșmada, spektral bant çeșitliliğine sahip, ücretsiz temin edilebilen, kaplama alanı büyük ve ziraat, ormancılık, arazi kullanım planlaması ve su kaynakları yönetimi gibi kullanım alanlarına sahip SENTINEL-2 MSI uydu görüntüsü tercih edilmiștir. SENTINEL-2 Coklu Tarama Enstrümanı (Multi-Spectral InstrumentMSI) $10 \mathrm{~m} 4$ bant, $20 \mathrm{~m} 6$ bant ve $60 \mathrm{~m}$ yersel çözünürlükte 3 bant olmak üzere 13 spektrum bantı örneklemektedir [30]. Bunun yanında SENTINEL-2 uyduları 2-3 günlük zamansal çözünürlüğe ve $290 \mathrm{~km}$ uzunluğundaki şerit genişliğine sahiptir. Araştırma sahası için, en az bulutluluk düzeyine sahip 08.02.2016 tarihli SENTINEL-2 görüntüleri (Level 1C) ESA SENTINEL web sitesinden temin edilmiștir.

Radyometrik Düzeltme: SENTINEL-2 uydu görüntüleri için dijital sayılarındaki (Digital Number-DN) sensör düzensizliklerinden kaynaklanan hataları gidermek amacı ile radyometrik kalibrasyon tekniği kullanılmıștır. Radyometrik kalibrasyonda DN değerleri, QGIS'in Semi-Automatic Classification Plugin (SACP) yarı otomatik sinıflandırma eklentisi kullanılarak Top of Atmosphere (TOA) yansımasına dönüştürülmüştür. Uydu görüntülerini kalibre etmek için, yerel güneș yükseklik açıları (local sun elevation angles), banda özgü çarpımsal yeniden ölçeklendirme faktörleri (band-specific multiplicative rescaling factors) ve banda özgü toplamsal yeniden ölçeklendirme faktörleri (band-specific additive rescaling factors) [31] dahil olmak üzere görüntülerin meta veri dosyaları SACP'ye entegre edilmiştir. Her yıl için DN'lerdeki hatalar, tüm görüntüleri standart bir ölçeğe getirmek için düzeltilmiştir.

Atmosferik Düzeltme: Tüm uydu görüntüleri için QGIS SACP eklentisinde Karanlık Nesne Çlkarma (Dark Object Subtraction-DOS) gerçekleștirilmiștir. Bu yöntem, uydu tarama zamanında atmosferik koşulların ve aerosol özelliklerinin saha ölçümleri hakkında bilgi eksikliği olduğunda kullanılır [32]. Çalışmada kullanılan uydu görüntülerinde, neredeyse sıfır yüzey yansımasına dayalı pikselleri (karanlık nesneler) temsil eden parlaklık değerleri, görüntünün diğer piksel değerlerinden çıkarılmıştır. Gölgeli alanlar (deniz veya koyu su yapıları ve koyu bitki örtüsü gibi koyu nesneler), bu düzeltme esnasında, uydu görüntülerinde siyah olarak tanımlanmaktadır [32, 33].

\subsubsection{Orman amenajman planı}

$\mathrm{Bu}$ çalışmada, araștırma sahasındaki orman alanları güncel uydu görüntüleri üzerinden sınıflandırılarak oluşturulmuştur. Ancak orman varlığı hakkında - ağaç türleri, meșcereler, ağaçların yaş ve büyüklükleri gibi - daha detaylı bilgi edinebilmek amaciyla İncecikler Orman İşletme Şefliği için orman amenajman planı verisi kullanılmıştır (Şekil 4).

Sahaya ait orman amenajman planına göre, İncecikler Orman İşletme Şefliğinde hâkim ağaç türleri kızılçam (Pinus brutia L.) ve fıstık çamı (Pinus pinea L.) olarak tespit edilmiştir.

\subsection{Yazılım}

Çalışma kapsamında CBS yazılımı olarak ArcGIS 10.4 [34] yazılımı, görüntü işleme amacıyla eCognition [35] ve elde edilen orman alanı katman verisinin var olan arazi kullanım/arazi deseni veritabanından alınan katman veri ile karşılaștırılması için TerrSet [36] yazılımı kullanılmıștır. Yöntem bölümünde de belirtildiği gibi, ArcGIS yazılımı veritabanı oluşturma, bant kompozitlerinin ve NDVI görüntüsünün hazırlanmasında ve çalışma kapsamında temin edilen ve üretilen veri katmanları ile sonuç haritalarının görselleștirilmesinde kullanılmıștır. eCognition yazılımı ise, yüksek çözünürlüklü SENTINEL-2 görüntülerinin segmentasyonu amacıyla kullanılmıştır.

\subsection{Yöntem}

\subsubsection{Bant kombinasyonları}

Uzaktan algılama ile elde edilen uydu görüntülerinin bantları, sahip oldukları farklı dalgaboyları ile farklı bilgileri içerirler [37]. SENTINEL-2 için doğal renk: 4-3-2, tarım: 11-82, kara/su: 8-11-4 vb. gibi farkl bant kombinasyonları (renk kompozitleri) farklı veriler üretme ve değerlendirmeler yapma imkânı sağlar. Bu çalıșmada, arazi örtüsünün / kullanımının ortaya konması için kırmızı (Bant 4), yeşil (Bant 3) ve mavi (Bant 2) bantların birleștirilmesi ile oluşturulan doğal renk kompoziti ve bitki örtüsünün görsel yorumu / sinıflandırılmasına olanak sağlayan ve yakın kızılötesi (NIR) (Bant 8), kırmızı (Bant 4) ve yeșil (Bant 3) bantların birleștirilmesi ile oluşturulan sahte renk kompoziti kullanılmıştır [38]. 


\section{DEÜ FMD 24(70), 165-178, 2022}

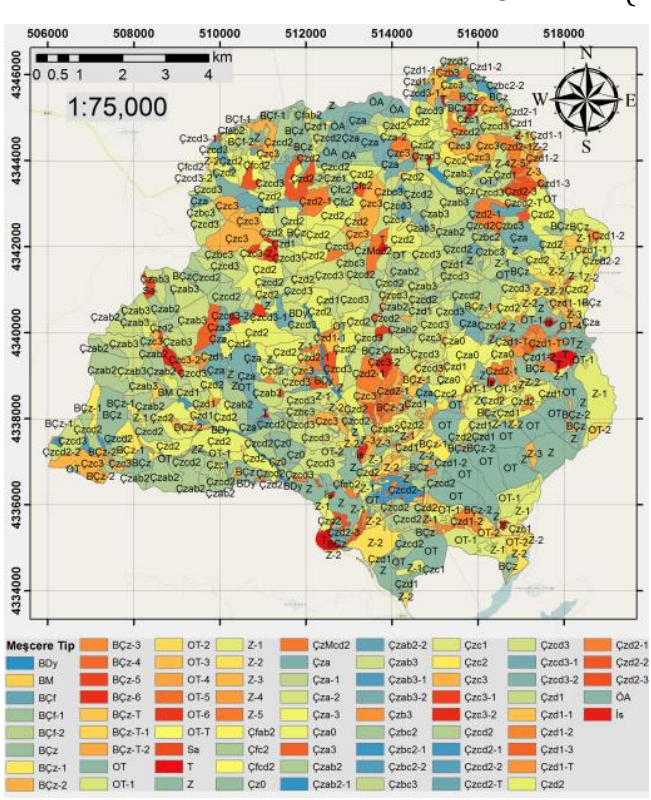

Şekil 4. Sahaya ait orman amenajman planı

\subsubsection{NDVI vejetasyon indeksi}

Bitkiler, fotosentez sırasında güneşten gelen elektromanyetik enerjinin kırmızı renge karşılık gelen dalgaboyunu kullanır. Bu yüzden, kırmızı ışığın yansımasını ölçen bir uydu görüntüsü, canlı bitki örtüsünün yoğun olduğu alanlarda düşük sayısal değerlere sahip olacaktır. Öte yandan yakın kızılötesi (NIR) dalga boyuna sahip elektromanyetik enerji bitki bünyesine alınmaz; su içeriğine bağlı olarak önemli ölçüde bitkinin iç katmanlarından yansitılır [37]. Sonuç olarak bitki örtüsünün bulunduğu alanlarda kırmızı renkte maksimum soğurma, yakın kızılötesinde ise maksimum yansıtılma gerçekleşir. Normalize edilmiș fark bitki örtüsü indeksi (Normalized Difference Vegetation Index, NDVI), kırmızı ve yakın kızılötesi bant görüntüleri kullanılarak üretilir [39]. Böylece bitki vejetasyonuna görsellik kazandırılır [15]. NDVI, Eşitlik 1'e göre hesaplanır ve $[-1,+1]$ aralığında değer alır.

$$
N D V I=\left(\frac{N I R-R E D}{N I R+R E D}\right)
$$

Bitki örtüsünün yoğun olduğu alanlara karşılık gelen pikseller, üretilen NDVI görüntüsünde yüksek sayısal değerlere (1'e yakın); bitki örtüsünün seyrek ya da sağlıksız olduğu alanlara karşılık gelen pikseller ise aynı görüntüde düşük sayısal değerlere (-1'e yakın) sahip olurlar [40]. Bu çalışmada SENTINEL-2 uydu görüntüsünün kırmızı bandı (Bant 4) ve yakın kızılötesi (NIR) bandı (Bant 8) kullanılarak ArcGIS yazılımı içinde NDVI görüntüsü oluşturulmuştur.

\subsubsection{Görüntü segmentasyonu}

Nesne tabanlı yaklaşımların temelinde görüntüyü belirli veya değişken büyüklükteki bölgelere (segmentlere) ayırıp bunlar üzerinde sınıflandırma yapmak yatmaktadır. Çalışmada kullanılan eCognition yazılımının görüntü segmentasyonu algoritması, spektral ve mekânsal ölçütlere göre birbirine yakın özellikteki pikselleri olabildiğince homojen parçalar olarak gruplandırmaktadır. Böylece tek piksellerden oluşan görüntü yerine, piksel gruplarından (daha anlamlı nesnelerden) oluşan bir görüntü ortaya çlkmaktadır [41,42]. Segmentasyon işlemi daha sonra uygulanacak görüntü sınıflandırma işleminin kalitesini önemli düzeyde arttırmaktadır. eCognition programında Çoklu Çözünürlüklü Segmentasyon ÇÇS (Multiresolution Segmentation - MRS) aracı ile gerçekleștirilen otomatik segmentasyon işlemi, araştırma sahası için temin edilen SENTINEL-2 uydu görüntülerinin orijinal bantları üzerinde uygulanmıştır. Vejetasyonu en iyi ortaya koyan görüntünün sahte renk kompoziti olduğu ve çalışmanın ana hedefinin orman alanlarını ayırmak olduğu göz önüne alındığında, segmentasyonun, SENTINEL-2 görüntülerinin NIR (bant 8), Kırmızı (bant 4) ve Yeşil (bant 3) bantları üzerinde yapılmasına karar verilmiştir. Araştırma sahası için uygulanan piksel bazında segmentasyon işleminde, çalıșma amacına en uygun segmentler oluşturulana kadar, ölçek, renk ve biçim parametreleri değiştirilerek en uygun segmentasyon seçeneğine karar verilmiştir. Burada ölçek parametresi ortaya çıkan nesnelerin boyutunu ve homojenliğini belirlemektedir [41]. Segmentasyon işlemi sonrası araştırma sahasına ait sahte renk kompoziti üzerinde eCognition yazılımında sınıflandırma işlemi gerçekleştirilmiştir. Sınıflandırmada orman, tarım (ekili alanlar) ve diğer arazi sınıfları olmak üzere 3 sınıf esas alınmıştır. Sınıflandırma işlemi için eCognition yazılımda segmentasyon parametreleri olarak ölçek (scale), yoğunluk (compactness) ve şekil (shape) parametreleri sirası ile $10,0.5$ ve 0.1 şeklinde seçilmiştir. Burada, şekil parametresi büyüdükçe, spektral özelliklere göre yüzey özelliklerinin gerçek durumu yansitılamayabileceği için şekil parametresi, 


\section{DEÜ FMD 24(70), 165-178, 2022}

orman alanlarının ortaya çıkartılmasında en düşük değerde seçilmiştir. Yoğunluk parametresinde ise değerin çok küçük seçilmemesi (orta seviyede), böylece görüntü üzerinde meydana gelen parçalanmanın (fragmentasyon) analizi zorlaştıracak şekilde olmaması sağlanmıştır [43]. Segmentasyon için her bir sınıfa ait 15 örnek seçilmiş ve sınıflandırma modülüne tanıtılmıştır. 15 örnek seçilmesinin sebebi, çalışma alanında bulunan orman alanları dışındaki tarım alanı ve diğer arazi kullanım sınıflarının alansal dağılımının örneklem sayısını arttırma gereksinimi oluşturacak ölçüde olmamasından kaynaklıdır. Burada örneklem ihtiyacı, biyokütle potansiyelinin hesaplanması amacı ile orman alanlarında yoğunlaşmıştır. eCognition yazılımında bu örneklere göre sinıflandırma işlem yapılmıştır.

\subsubsection{Orman gelişim sınıflarının tespiti}

Çalışmanın bir önceki aşamasında güncel uydu görüntüsünden segmentasyon ile üretilen orman alanları verisi (vektör veri formatında) orman amenajman planındaki veriler ile karșılaștırılmıș ve orman amenajman planındaki [44] gelişim çağı sınıfı verisi uydu görüntüsünden elde edilen veriye eklenerek orman alanları verisi güncellenmiștir. Uydu görüntüsünden üretilen orman alanları verisi ile orman amenajman planı verisi birleștirilmesiyle orman alanlarındaki meșcere tipleri elde edilmiştir. Meşcere tiplerinin çağlar ve gelişim sınıflarına göre sıralaması ise Tablo 1'de verilmiștir.

Tablo 1. İğne yapraklı ağaçlar için meşcere gelişim çağları [45] ve toprak üstü biyokütle (TÜB) [46] sinıflaması.

\begin{tabular}{lccc}
\multicolumn{1}{c}{ Çağ } & $\begin{array}{c}\text { Gelişim } \\
\text { Sınıfı }\end{array}$ & $\begin{array}{c}\text { Ağaç Çapı } \\
\text { (cm) }\end{array}$ & $\begin{array}{c}\text { TÜB } \\
\text { (ton/ha) }\end{array}$ \\
\hline $\begin{array}{l}\text { Gençlik } \\
\text { Sıklık }\end{array}$ & a & $0-8$ & 10 \\
Sırıklık & & & \\
Direklik & b & $8-20$ & 88 \\
İnce ağaçlık & c & $20-36$ & 165 \\
Orta ağaçlık & d & $36-52$ & 225 \\
Kalın ağaçlık & e & $>52$ & 300 \\
\hline
\end{tabular}

Tablo 1'de IPCC'nin tanımlamasına göre orman ağacı yaşı ile gelişsim sınıfları arasında bir ilişki kurulmuștur. Hatta bu ilișki IPCC'nin Ulusal Sera Gazı Envanterleri için Rehber: Tarım, Ormancılık ve Diğer Arazi Kullanımı raporunda [46] belirtildiği üzere iğne yapraklı ağaçlar ve geniş yapraklı ağaçlar arasında bile çeşitlenmektedir. Burada izlenen yönteme göre sinıflar genel olarak aşağıdaki gibi kabul edilmektedir [46]:

- a: 0-20 yll

- b: 21-40 yll,

- c: 41-60 yll,

- $\mathrm{d}:$ 61-80 yll,

- $\quad$ e: 81-200 yll ve sonrası

$\mathrm{Bu}$ değerlerin hesaplanması sırasında izlenen yöntem ise aynı rapordan alınarak Tablo 2'de aktarılmaktadır.

Tablo 2. İğne yapraklı ağaçlar için ılıman iklimin yașandığı yerlerde biyokütle dönüșüm formülleri [46].

\begin{tabular}{c|c|c|c|c|c}
\hline \multirow{2}{*}{ BCEF } & \multicolumn{5}{|c}{ Büyüyen stok seviyesi $\left(\mathrm{m}^{3}\right)$} \\
\cline { 2 - 6 } & $<20$ & $21-40$ & $41-100$ & $\begin{array}{c}100- \\
200\end{array}$ & $>200$ \\
\hline BCEFs & $\begin{array}{c}1.8 \\
(0.6- \\
2.4)\end{array}$ & $\begin{array}{c}1.0 \\
0.65-\end{array}$ & $\begin{array}{c}0.75 \\
0.6- \\
1.0)\end{array}$ & $\begin{array}{c}0.7 \\
0.4- \\
1.0)\end{array}$ & $\begin{array}{c}0.7 \\
0.4- \\
1.0)\end{array}$ \\
\hline BCEF $_{\mathrm{I}}$ & 1.5 & 0.75 & 0.6 & 0.67 & 0.69 \\
\hline BCEF $_{\mathrm{R}}$ & 2.0 & 1.11 & 0.83 & 0.77 & 0.77 \\
\hline
\end{tabular}

BCEF: Biomass Conversion and Expansion Factor (Biyokütle Dönüşüm ve Genişleme Faktörü)

$\mathrm{BCEF}_{\mathrm{S}}$ : Expansion of merchantable growing stock volume to aboveground biomass (Satılabilir büyüyen stok hacminin yer üstü biyokütleye genişletilmesi)

BCEFI: Conversion of net annual increment (Net yıllık artışın dönüștürülmesi)

$\mathrm{BCEF}_{\mathrm{R}}$ : Conversion of wood and fuelwood removal volume to aboveground biomass removal (Odun ve yakacak odun giderme hacminin yer üstü biyokütle giderimine dönüştürülmesi)

IPCC'nin Tablo 2'de izlenen yöntem ile belirlediği ve Tablo 1'de verilen genel TÜB değerleri, çalıșma alanında bulunan orman alanlarının meșcere verilerine göre kullanılmıştır. Ancak çalıșma alanında, ormanın doğal karışık yapısı nedeniyle bazı meşcerelerde karışık bir yapı yani birden çok gelişim çağı sınıfı olduğu belirlenmiştir. Bu yapı, meşcere tipinde 


\section{DEÜ FMD 24(70), 165-178, 2022}

Çzab2 ya da Çzcd gibi sinıflamalarda görünmektedir. Orman biyokütle potansiyeli, meşcere gelişim çağlarına göre tanımlandığından, çalışmada, birden çok sınıf bilgisi içeren meşcere gelişim çağları olan ab gelişim sınıfı b sınıfı ve cd gelişim sınıfı d sınıfı olarak yeniden sınıflandırılmıştır.

\subsubsection{Biyokütle potansiyelinin haritalanması}

Eastman $[47,48]$ tarafından da belirtildiği gibi, orman alanları karbon (biyokütle) verileri, örnek parsel alan ölçümlerinden veya mevcut orman envanteri verilerinden elde edilebilir. Ancak alan verileri mevcut değilse, ormanlara ait karbon kaynakları ve karbon havuz hesaplamaları için önerilen yöntem IPCC'nin Ulusal Sera Gazı Envanterleri için Rehber: Tarım, Ormancılık ve Diğer Arazi Kullanımı (Guidelines for National Greenhouse Gas Inventories: Agriculture, Forestry and Other Land Use) [46] Raporunda verilen yöntemdir $[47,48]$.

IPCC [46], orman arazisi ve orman alanına dönüșen arazide biyokütle, ölü organik madde ve toprak organik karbonundaki değişiklikler nedeniyle sera gazı emisyonlarının ve emisyon azaltımının tahmin edilmesi için yöntemler sunmaktadır. Orman biyokütlesi tahmininde toprak üstü orman biyokütlesi, ölü organik madde, toprak organik maddesi ve $\mathrm{CO}_{2}$-dişı gazlar için hesaplamalar sunan yöntemde, orman kaybı ve farklı arazi kullanım tiplerinden ormana dönüșen arazilerin karbon (biyokütle) hesapları verilmektedir. Bu kapsamda, arazi verisi olmayan çalışmalarda yapılacak hesaplamalar için birim alan (ha) bașına ormanlardaki toprak üstü orman biyokütlesi değerleri (ton/ha) kıta ve iklim bölgelerine göre sunulmaktadır. Bu çalışmada, uydu görüntüleri ile elde edilen orman alanları için ve orman amenajman planı ile güncellenen gelişim çăğ bilgisi de kullanılarak Tablo 1'de verilen IPCC'nin toprak üstü biyokütle değerleri esas alınmıștır.

\section{Bulgular}

\subsection{SENTINEL-2 Bant Kombinasyonları}

Calıșma kapsamında araștırma sahası olan İncecikler Orman İșletme Șefliği için temin edilen SENTINEL-2 uydusuna ait Bant 2 - Mavi, Bant 3 - Yeşil, Bant 4 - Kırmızı ve Bant 8 - NIR bantları ile segmentasyonda kullanılmak üzere doğal renk ve sahte renk kompozitleri, ArcGIS yazılımının Image Analysis araç seti kullanılarak hazırlanmıştır (Şekil 5).

\subsection{NDVI Vejetasyon İndeksi}

NDVI, SENTINEL-2 uydusunun kırmızı (Bant 4) ve NIR (Bant 8) bantları kullanılarak ArcGIS yazılımı içinde oluşturulmuştur. Araştırma sahası için elde edilen $10 \mathrm{~m}$ çözünürlüklü NDVI görüntüsü Şekil 6'da verilmiştir. Sahaya ait NDVI değerlerinin 0.21 ile 0.698 arasında değiștiği saptanmıștır.
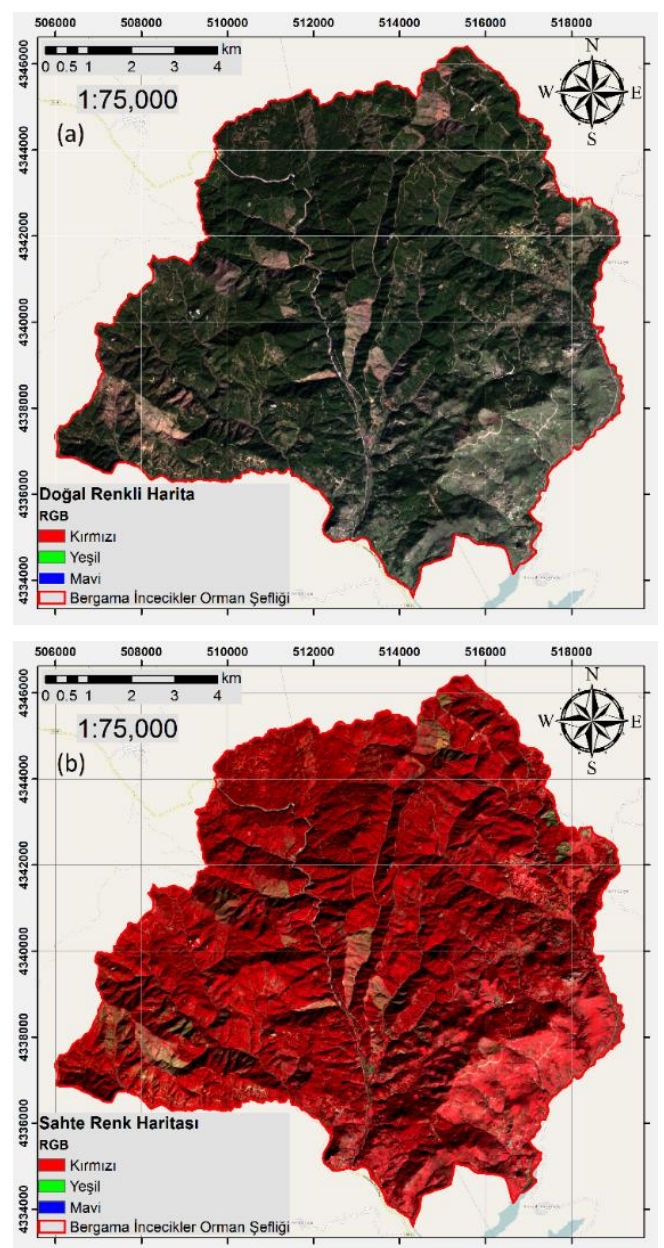

Şekil 5. Doğal renk ve sahte renk kompoziti

\subsection{Sınıflandırılmış Uydu Görüntüsü}

Görüntü segmentasyonu ve sinıflandırması sonucunda araştırma sahası için belirlenen orman ve orman dișı alanlar, sahte renk kompozitinin ÇÇS aracı ile sınıflandırılması sonucunda üretilmiştir (Şekil 7). Burada, eCognition yazılımında segmentasyon 


\section{DEÜ FMD 24(70), 165-178, 2022}

işlemlerini takip eden süreçte yapılan sınıflandırma sonrasında, ayrıca doğruluk değerlendirmesi de yapılmıştır. Piksel bazında doğruluk değerlendirmesine bakıldığında ortalama değerler orman için 0.903, tarım (ekili alanlar) için 0.668 ve diğer arazi sınıfları için 0.276 olarak bulunmuştur.

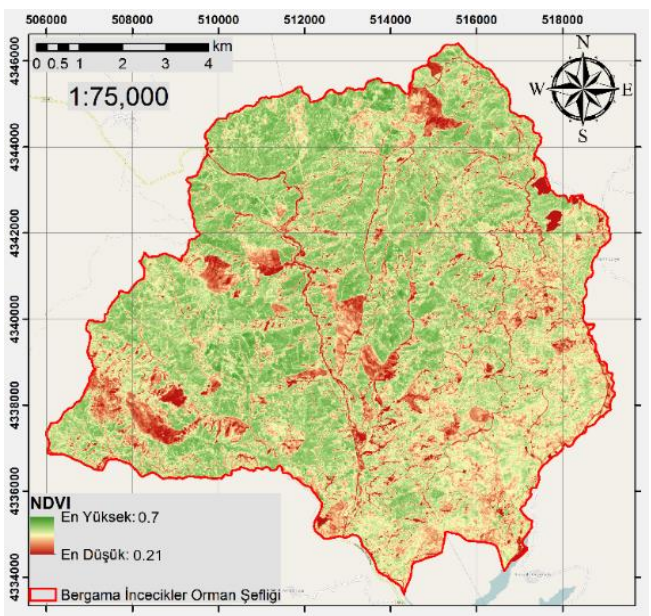

Şekil 6. Saha NDVI görüntüsü

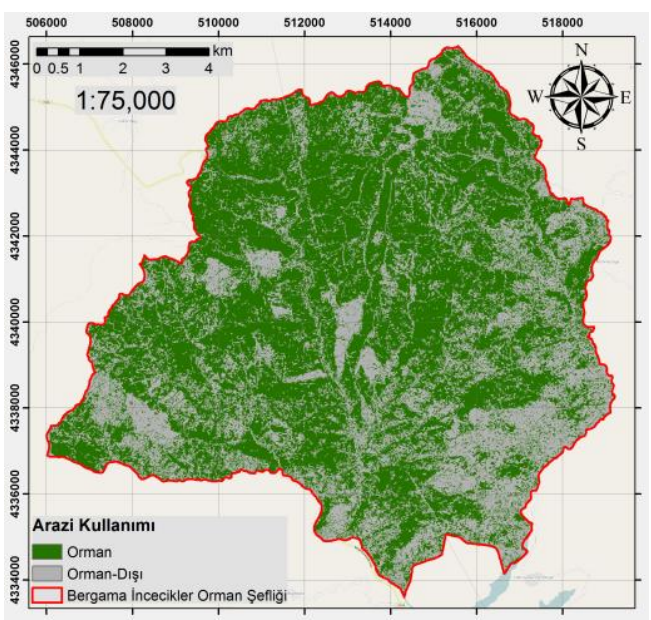

Şekil 7. ÇÇS'na göre orman / orman dışı alanlar

Uydu görüntüsünden sınıflandırma ile (Șekil 7) tespit edilen orman dişı alanların orman amenajman planında (Şekil 4) ziraat ve orman toprağı ve yer yer bozuk alanlardan oluştuğu görülmüştür. Ancak, uydu görüntülerinden sınıflandırma ile tespit edilen orman alanları ile orman amenajman planındaki orman alanları büyüklükleri arasında fark olması, orman amenajman planının güncel uydu görüntüleri ile güncellenmesi gerektiğini ortaya koymaktadır. Çalışmada ÇÇS ile tespit edilen güncel orman alanları esas alınmıştır.

Sınıflandırılmış orman alanları görüntüsü (Şekil 7) arazi kullanım/arazi deseni ile ilgili var olan çalışmalar ile ayrıca kıyaslanmak istenmiştir. Bu amaçla, Avrupa Uzay Ajansı'nın İklim Değișikliği Girişimi (European Space Agency (ESA) Climate Change Initiative (CCI)) tarafindan 1992 yılından günümüze kadar üretilen arazi kullanım/arazi deseni haritaları ile karşılaştırma yapılmıştır. Karșılaștırmanın yapılması için öncelikle 2016 yılına ait ESA CCI LC (land cover) verisi https://cds.climate.copernicus.eu/ linkinde yer alan veritabanından temin edilmiştir. Elde edilen $300 \mathrm{~m}$ yersel çözünürlüğe sahip görüntüde, orman alanları belirlenmiș ve çalıșma alanına göre maskelenmiştir. Elde edilen ESA CCI LC orman alanı katmanı ile çalışma kapsamında üretilen orman alanı katmanı TerrSet ortamında ROC analizine tabi tutulmuştur.

ROC (Receiver Operating Characteristic) yöntemi, her grid hücresinde aynı sınıfı tahmin eden herhangi bir model için çalışır. Uzman, ROC'yi ikiden fazla arazi örtüsü sınıfı için kullanabilir veya her arazi örtüsü sınıfı için bir ROC gerçekleştirebilir [49]. Çalışma kapsamında yapılan ROC analizinde, "eşit ağırlıklı eşik değeri" tipine göre eșik değeri sayısı 1000 olarak seçilmiştir. İki katman veri arasındaki AUC değeri 0.822 olarak bulunmuş olup; karşılaştırma değerinin yüksek olduğu görülmüştür. Aradaki farklılıklar iki katman verinin yersel çözünürlüklerinin birbirinden farklı olması şeklinde yorumlanabilir. ESA CCI LC verisinin orman alanlarını gösterdiği verinin çözünürlüğü çalışmada üretilen orman alanı verisine göre düşüktür. $\mathrm{Bu}$ da AUC değerinin \%82 civarında olmasını açıklamaktadır.

\subsection{Orman Gelișim Sınıfları}

Uydu görüntüsünden segmentasyon ile ayrılan orman alanları verisi (Şekil 7), orman amenajman planındaki (Șekil 4) veriler ile karşılaştırılmış ve orman amenajman planındaki gelişim çağı sınıfı verisi, uydu görüntüsünden üretilen orman / orman dışı sınıfı verisine eklenerek orman alanları verisinin güncellenmesi sağlanmıștır. Bu yolla ayrıca, uydu görüntüsünden elde edilen orman alanları verisi ile orman amenajman planı verisi birleștirilmiş ve orman alanlarındaki meșcere tipleri elde edilmiştir (Șekil 8). Bu meșcere 


\section{DEÜ FMD 24(70), 165-178, 2022}

tiplerinin Kızılçam (Çz-Pinus brutia) ve Fistıkçamı (Çf-Pinus pinea) olduğu belirlenmiştir. Bu ağaçların $\mathrm{a}, \mathrm{b}, \mathrm{c}$, ve d gelișim çağlarındaki türlerinin de bulunduğu görülmüştür. Buradaki ağaçlar kozalaklı ağaç (conifer) yapısına girmektedir.

Uydu görüntüsünden elde edilen orman alanları sınıflandırma katmanına göre orman amenajman planında orman dişı alanlar (su, otlak, bozuk yapıdaki orman alanları vb.) daha sonraki aşamalar için değerlendirme dişı olarak değerlendirilmiştir. Bu sayede, orman dışı alanlar (su, otlak, vb.) ile bozuk yapıdaki orman alanları hariç bırakılmıştır. Araştırma bölgesi için uydu görüntülerinin sahte renk kompozitinin segmentasyonu sonucu elde edilen ve orman amenajman planı verisinin güncellenmesini sağlayan orman alanları, gelişme çağlarına göre haritalanmıştır. Orman amenajman planına göre belirlenen gelişim çağlarına göre orman alanları büyüklükleri, Tablo 1 esas alınarak, a, b, c ve d sınıfı için sırasıyla 391.4 ha, 755.5 ha, 693.9 ha ve 3205 ha olarak belirlenmiştir.
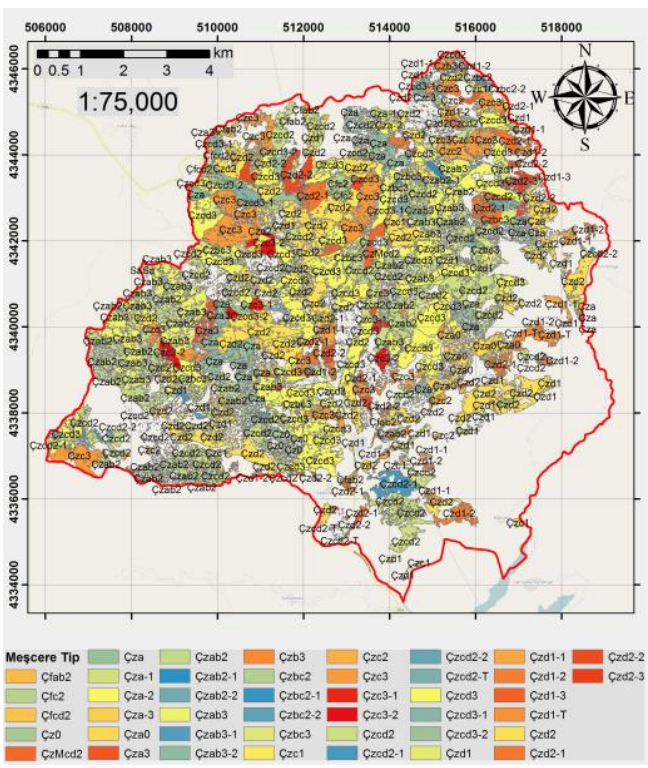

Şekil 8. Güncellenen orman amenajman planı

\subsection{Toprak üstü Biyokütle Potansiyeli}

Uydu görüntüsünden elde edilen ve orman amenajman planı verilerinin güncellenmesini sağlayan güncel orman alanları verisi ile IPCC (2016)'nın orman gelişim çağına göre önerdiği toprak üstü orman biyokütle potansiyeli değerleri (Tablo 1) kullanılarak araștırma sahasına ait biyokütle potansiyeli haritası oluşturulmuştur (Şekil 9).

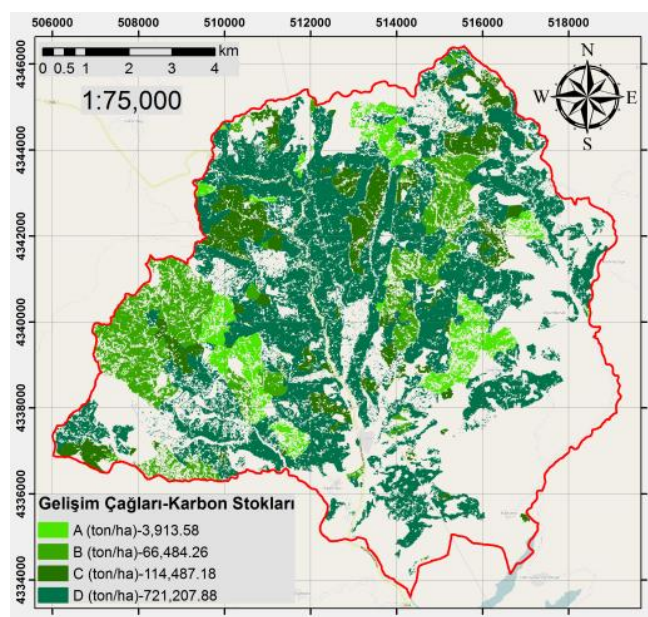

Şekil 9. Araştırma sahası için toprak üstü orman biyokütle potansiyeli.

\section{Sonuçlar}

Biyokütle potansiyelinin ve alansal dağılımının belirlenmesi ve biyokütle stoklarının izlenmesi, biyokütleden enerji temini sistemlerinin planlaması, tasarımı ve işletimi için kritik öneme sahiptir. Bu tür projelerin ekonomik ve teknik uygulanabilirliği için, biyokütle kaynağının mevcut olduğu alanların saptanmasına, biyokütle hammaddesinin sürekli temin edilebileceğinin doğrulanmasına ve biyokütle malzemesinin temini için gerekli tașıma maliyetlerinin bilinmesine ihtiyaç vardır.

Biyokütle potansiyelinin ve bu potansiyelin alansal değișiminin UZ-AL ve CBS ile saptanmasında geliștirilen ve daha yüksek doğrulukla sonuç veren yöntemler arazi çalışması ile elde edilen ölçümlere ya da aktif uydulardan alınan LIDAR gibi görüntülerin baz alındığı çalışmalara dayanır. Orman alanları gibi büyük alanlarda arazi ölçümü gerçekleştirmek, ölçüm noktalarının sayıca çok olması ile analiz doğruluğunun artması dikkate alınırsa oldukça zaman alıcl, pahalı ve emek isteyen bir çalışmadır.

Tüm bu hususları dikkate alan bu çalıșma, arazi ölçümü olmadan orman biyokütlesi potansiyelinin kestirimi için yeni bir yaklaşım ortaya koymaktadır. Bu yöntem özellikle orman biyokütlesi için ön değerlendirme yapma vb. 


\section{DEÜ FMD 24(70), 165-178, 2022}

çalıșmalar için hızlı sonuç veren bir yöntemdir. Burada kullanılan jeoistatistiksel yaklaşım ve IPCC tarafından geliştirilen bağıntılar ile elde edilen ve kullanılan orman gelişim tiplerine göre karbon depolama değerleri, çalışma sahasında bulunan farklı gelişim çağlarına sahip orman alanlarının ne kadar karbon depoladığı hakkında bilgi vermektedir.

Çalışmada önemli olan bir diğer husus ise çözünürlüğü yüksek güncel uydu verilerinin nesne tabanlı sınıflandırma yöntemi aracılı̆̆ıyla sınıflandırılması ve çalıșma sahasında bulunan güncel orman alanlarının tespit edilmesidir. Böylelikle oluşturulmuş meşcere haritasının da güncellenmesi sağlanarak orman planlamacılığına katkıda bulunulmuştur.

Bu çalıșmaya ek olarak çalıșma sahasının gelecek yıllarda yüksek çözünürlüklü pasif uydular ve/veya aktif uydular ile izlenmesi sağlanacak ve orman alanlarında gerçekleșen değișim ile karbon stoğunda meydana gelen değișiklikler analiz edilebilecektir. Böylelikle bu çalıșmanın çıktıları ile gelecek yıllarda yapılacak çalışma çıtılarının karşılaştırılması sağlanacaktır. Bunun yanı sıra yapılması planlanan bir diğer çalışma ise gelecek yıllara ait orman alanı modellemeleri ile karbon stoğunda meydana gelebilecek değişikliklerin tahminlenmesine yöneliktir.

Teşekkür: Yapıcı eleştirilerinden dolayı hakemlere teșekkür ederiz.

\section{Kaynakça}

[1] Yolasığmaz, H.A., Cavdar, B., Demirci, U., Aydın, İ.Z 2016. İki farklı yönteme göre karbon birikiminin tahmin edilmesi: Artvin Orman İşletme Şefliği örneği, Turkish Journal of Forestry, Cilt: 17(1), s. 43-51. DOI: $10.18182 /$ tjf.20323.

[2] Erlat, E. 2014. İklim Sistemi ve İklim Değişmeleri. Ege Üniversitesi Yayınları Edebiyat Fakültesi No: 155, 5. Baskı, İzmir.

[3] Piyaphongkul, J., Gajaseni, N., Na-Thalang, A. 2011. A comparative study of carbon sequestration potential in aboveground biomass in primary forest and secondary forest, Khao Yai national park. Atazadeh, I., ed. 2011. Biomass and Remote Sensing of Biomass, InTechOpen, ISBN: 978-953-307-490-0.

[4] Orman Genel Müdürlüğü (OGM) 2009. Orman Genel Müdürlüğü'nde Biyoenerji Konusunda Yapılan Çalışmalar. Orman Genel Müdürlüğü Biyoenerj Calıșma Grubu.

[5] Matthews, E., Payne, R., Rohweder, M., Murray, S. 2000. Forest Ecosystems. World Resources Institute, ISBN: 1-56793-459-3.
[6] Gibbs, H.K., Brown, S., Niles, J.O., Foley, J.A. 2007. Monitoring and estimating tropical forest carbon stocks: Making REED a reality. Environmental Research Letter, Vol. 2, s. 1-13. DOI: 10.1088/17489326/2/4/045023.

[7] UNCCD \& Joint Liaison Group of the Rio Conventions. 2007. Forest-Climate Change, Biodiversity and Land Degradation. United Nations Secretariat of the Convention to Combat Desertification (UNCCD), and United Nations Framework Convention on Climate Change (UNFCCC), United Nations.

[8] Ayoubi, S., Shahri, A.P., Karchegani, P.M., Sahrawat, K.L. 2011. Application of Artificial Neural Network (ANN) to Predict Soil Organic Matter Using Remote Sensing Data in Two Ecosystems. Atazadeh, I., ed. 2011. Biomass and Remote Sensing of Biomass, InTech, Rijeka, Croatia.

[9] Yavaşll, D.D. 2013. Toprak Üstü Orman Biyokütlesi Belirleme Çalışmalarında ICESat/GLAS Verilerinin Kullanımı. ss 951-959. Öner, E., ed. 2013. İlhan Kayan'a Armağan Kitabı.

[10] Aydın, F., Sarptaș, H. 2016. Coğrafi bilgi sistemleri ve uzaktan algılama ile orman kaybının analizi ve gelecekteki orman varlı̆̆ının tahmini. GEFiK-2016 İzmir Genç Fizikçiler Kongresi, 12-13-14 Ekim, İzmir.

[11] Aydın, F. 2016. Uzaktan algılama ve CBS teknikleri ile değerlendirilen ormansızlașma kaynaklı arazi değişimi altında günümüz ve gelecek orman biyoçeșitliliğinin analizi: Bornova, İzmir örneği. Ege Coğrafya Dergisi, Cilt: 25 (2), s. 15-35.

[12] Çabuk, A., Avdan, U., Cömert, R., Uyguçgil, H., Şorman, A., Küpçü, S., Bektöre, E., Ișık, Ö. 2011. Coğrafi Bilgi Sistemleri, Anadolu Üniversitesi Açıköğretim Fakültesi Yayını. ISBN: 978-975-06-0920-6, Eskișehir.

[13] Kavzoğlu, T., Çölkesen, İ. 2017. Uzaktan algılama teknolojileri ve uygulama alanları. http://www.gtu.edu.tr/Files/UserFiles/80/jeodezi/ yayinlar/pdf/kavzoglu Colkesen Calistay.pdf (Erișim Tarihi: 10.03.2017).

[14] Düzgün, S. 2010. Uzaktan Algllamaya Giris Ders Notları. Ulusal Açı Ders Malzemeleri Konsorsiyumu-TÜBA, Ankara.

[15] Ashraf, M.A., Maah, M.J., Yusoff, I. 2011. Introduction to Remote Sensing of Biomass, Atazadeh, I., ed. 2011. Biomass and Remote Sensing of Biomass. InTech, Rijeka, Croatia.

[16] Meinel, G., Neubert, M. 2004. A comparison of segmentation programs for high resolution remote sensing data. International archives of the photogrammetry, Remote Sensing and Spatial Information Sciences, 35.

[17] Altınbaș, Ü. 2006. Toprak Etüd ve Haritalama. Ege Üniversitesi Ziraat Fakültesi Yayınları. 2. Baskı, No:521, ISBN: 975-483-703-1, Bornova, İzmir.

[18] Aydoğdu, M., Tarini, M., Akçar, H.T., Aydemir, A. 2009. Harran ovasında coğrafi bilgi sistemleri ve uzaktan algılama ile tarım arazilerinde amaç dışı kullanımın 


\section{DEÜ FMD 24(70), 165-178, 2022}

tespiti. TMMOB Coğrafi Bilgi Sistemleri Kongresi, 0206 Kasım, İzmir.

[19] Askar, Nuthammachot, N., Phairuang, W., Wicaksono, P., Sayektiningsih, T. 2018. Estimating Aboveground Biomass on Private Forest Using Sentinel-2 Imagery. Journal of Sensors. DOI: 10.1155/2018/6745629.

[20] Goodenough, D.G., Niemann, K.O., Dyk, A., Hobart, G., Gordon, P., Loisel, M., Hao, C 2008. Comparison of AVIRIS and AISA airborne hyperspectral sensing for above-ground forest carbon mapping. Geo-science and Remote Sensing Symposium, IEEE International 129-132.

[21] Verkerk, P.J., Fitzgerald, J.B., Datta, P., Dees, M., Hengeveld, G.M., Lindner, M., Zudin, S. 2019. Spatia distribution of the potential Forest biomass availability in Europe. Forest Ecosystems, Cilt: 6(5) DOI: 10.1186/s40663-019-0163-5.

[22] Özkan, U.Y. 2003. Uydu Görüntüleri Yardımıyla Meşcere Parametrelerinin Kestirilmesi ve Orman Amenajmanında Kullanılması Olanakları. Yüksek Lisans Tezi, G.Ü., Fen Bilimleri Enstitüsü, İstanbul.

[23] Sivrikaya, F., Keleș, S., Çakir, G., Bașkent, E.Z., Köse, S. 2006. Comparing accuracy of classified Landsat data with landuse maps reclassified from the stand type maps. 7th International Symposium On Spatial Accuracy Assessment in Natural Resources and Environmental Sciences.

[24] Chhabra, A., Palria, S., Dadhwal, V.K. 2002. Growing stock-based forest biomass estimate for India. Biomass and Bioenergy, Cilt:22, s. 187-194. DOI: 10.1016/S0961-9534(01)00068-X.

[25] Iverson, L.R., Brown, S., Prasad, A., Mitasova, H., Gillespie, A.J.R., Lugo, A.E. 1994. Use of GIS for Estimating Potential and Actual Forest Biomass for Continental South and Southeast Asia. Dale, V.H., ed Effects of Land-Use Change on Atmospheric $\mathrm{CO}_{2}$ Concentrations. Ecological Studies (Analysis and Synthesis). vol 101. Springer, New York.

[26] Hongrui, R., Guangsheng, Z., Xinshi, Z. 2011. Estimation of green aboveground biomass of desert steppe in Inner Mongolia based on red-edge reflectance curve area method. Biosystems Engineering, Cilt:109, S. 385-395 DOI:10.1016/j.biosystemseng.2011.05.004.

[27] Timothy, D., Onisimo, M., Cletah, S., Adelabu,, S., Tsitsi, B. 2016. Remote sensing of aboveground forest biomass: A review. Tropical Ecology, Cilt: $57(2)$, s. $125-132$

[28] NASA/METI/AIST/Japan Space Systems and U.S./Japan ASTER Science Team 2001. ASTER Global Digital Elevation Model V003 [Data set]. NASA EOSDIS Land Processes DAAC.

[29] Copernicus 2016. CORINE Land Cover. https://land.copernicus.eu/pan-european/corineland-cover (Erișim Tarihi: 12.01.2016).

[30] European Space Agency (ESA) 2016. SENTINEL-2 MSI User Guide. https://earth.esa.int/web/sentinel/userguides/sentinel-2-msi/ (Erişim Tarihi: 20.02.2016).

[31] Humboldt State University 2017. Introduction to Remote Sensing: Radiometric Corrections. http://gsp.humboldt.edu/olm_2015/Courses/GSP_ 216_Online/lesson4-1/radiometric.html (Erişim Tarihi: 20.10.2017).

[32] Zhang, Z., He, G., Wang, X. 2010. A practical DOS model-based atmospheric correction algorithm. International Journal of Remote Sensing, 31(11):2837-2852 10.1080/01431160903124682, 2010.

[33] Kaufman, Y.J., Sendra, C. 1988. Algorithm for automatic atmospheric corrections to visible and near-IR satellite imagery. International Journal of Remote Sensing, Cilt: 9, s. 1357-1381. DOI: $10.1080 / 01431168808954942$.

[34] Environmental Systems Research Institute (ESRI) 2015. https://www.esri.com/en-us/home. (Erişim Tarihi: 20.10.2015).

[35] Trimble Geospatial 2016. http://www.ecognition.com/. (Erişim Tarihi: 05.01.2016).

[36] TerrSet 2016. https://clarklabs.org/terrset/. (Erișim Tarihi: 10.02.2016).

[37] Sunar, F., Özkan, C., Osmanoğlu, B. 2013. Uzaktan Algılama. Anadolu Üniversitesi Yayını. No: 2320.

[38] Esetlili, M.T., Kurucu, Y. 2003. Uzaktan alglama tekniği ile pamuk ekili alanların belirlenmesinde kontrollü (supervised) sınıflandırma yöntemlerinin irdelenmesi üzerine bir araştırma. Ege Üniversitesi Ziraat Fakültesi Dergisi, Cilt:40(2), s. 105-112.

[39] Weier, J., Herring, D. 2017. Measuring vegetation (NDVI\&EVI)

https://earthobservatory.nasa.gov/features/Measu ringVegetation. (Erişim Tarihi: 06.06.2017).

[40] Gündoğdu, K.S., Bantchina, B.B. 2018. Landsat uydu görüntülerinden NDVI değer dağlımının parsel bazlı değerlendirilmesi, Uludağ Üniversitesi Ziraat Fakültesi çiftlik arazisi örneği. Bursa Uludağ Üniversitesi Ziraat Fakültesi Dergisi, Cilt: 32(2), s. 45-53.

[41] Belgiu, M., Csillik, 0. 2018. Sentinel-2 cropland mapping using pixel-based and object-based timeweighted dynamic time warping analysis. Remote Sensing of Environment, Cilt: 204, s. 509523. DOI: $10.1016 /$ j.rse.2017.10.005

[42] Baatz, M., Schäpe, A. 2000. Multiresolution Segmentation-an optimization approach for high quality multi-scale image segmentation. ss. 12-23. Strobl, J, Blaschke, T., Griesebner, G., ed. 2000. Angewandte Geographische Informationsverarbeitung. Wichmann-Verlag, Heidelberg.

[43] Zheng, L. 2015. Parameter optimization in multiscale segmentation of high resolution remotely sensed image and its application in object-oriented classification. 2015 International Conference on 
DEÜ FMD 24(70), 165-178, 2022

Environmental Engineering and Remote Sensing (EERS2015).

[44] Orman ve Su İșleri Bakanlı̆̆ı 2017 http://corine.ormansu.gov.tr/corineportal/turkiyec alismalar.html. (Erişim Tarihi: 04.10.2017).

[45] Başkent, E.Z. 2006. Orman Amenajmanı-Orman Envanteri (Ders Notları). Karadeniz Teknik Üniversitesi,

http://www.ktu.edu.tr/dosyalar/15 0103 56c61.p df. (Erişim Tarihi: 20.10.2017)

[46] International Panel of Climate Change (IPCC) 2006 IPCC Guidelines for National Greenhouse Gas Inventories: Agriculture, Forestry and Other Land Use. Volume 4.

[47] Eastman, J.R. 2015a. Terrset Manual, Clark Labs, Clark University.

[48] Eastman, J.R. 2015b. Terrset Tutorial, Clark Labs, Clark University.

[49] Pontius, R.G., Schneider. L.C. 2001. Land-cover change model validation by an ROC method for the Ipswich watershed, Massachusetts, USA. Agriculture, Ecosystems and Environment, Cilt: 85, s. 239-248. DOI: $10.1016 / \mathrm{S} 0167-8809(01) 00187-6$. 